\title{
TANGGUNG JAWAB PIDANA KORPORASI RUMAH SAKIT
}

\author{
Oleh: Hasrul Buamona \\ Praktisi Hukum \\ E-mail: asrul.rul36@yahoo.com
}

\begin{abstract}
Hospital is an institution that provides comprehensive health services on preventive, promotive, curative and rehabilitative to the public at largeas regulated in Article 1 (3) of Law Number 44 Year 2009 About the Hospital, which says "Comprehensive health services are health services which include promotive, preventive, curative, and rehabilitative services. In addition, the hospital is an institution that dense of capital, technology and human resources, so it could potentially cause problems both internally and externally. The hospital previously regarded as a social institution that provides medical assistance to the public, but in the present position of the hospital has experienced changes, which had shaped a social institution become an institution in the form of a corporation incorporated under the law which have the rights and obligations as a legal person (rechts persoon) that lead to a dominant profit-seeking health services. Issues that have sprung up in the present, in case of medical errors by physicians or health workers who work in hospitals and provide economic or moral benefits, patients litigate doctors, especially criminal law, and never asked the corporate criminal liability of hospital that the establishment has a legal entity (rechts persoon). That issue makes the writer interested in reviewing whether the hospital as a corporation can be held criminally liable. The result of this study showed that the hospital can be held criminally liable because a hospital as a corporation is a legal person (rechts persoon) who have rights and obligations as well as a natural person (naturlijke persoon). Besides, the legal doctrine of Vicarious Liability and Strict Liability hold that there can be a person liable for the actions of his employees as far as the employment relationship in a hospital/corporation.
\end{abstract}

Keywords: Criminal Liability, Corporation, Hospital

\section{A. LATAR BELAKANG}

Persoalan perbaikan kesehatan pasien secara keseluruhan dikelola oleh Rumah Sakit, baik perbaikan kesehatan promotif, preventif, kuratif dan rehabilitatif, hal tersebut sebagaimana diatur dalam UU Nomor 36 Tahun 2009 Tentang Kesehatan. Hal ini juga berkaitan dengan asas dan tujuan hadirnya rumah sakit, yang harus dis-elenggarakan berasaskan Pancasila dan didasarkan kepada nilai kemanusiaan, etika dan profesionalitas, manfaat, keadilan, persamaan hak dan anti diskriminasi, pemera-taan, perlindungan dan keselamatan pasien, serta mempunyai fungsi sosial. Tata kelo-la pelayanan kesehatan demi terpenuhinya kesembuhan pasien yang paripurna tidak hanya berada di tangan dokter ataupun dokter gigi, sebagai tenaga kesehatan yang dalam tindakan kedokterannya terhadap pasien di rumah sakit, tidak bisa lepas dari kesalahan tindakan kedokteran. 
Kesehatan merupakan hak asasi manusia dan salah satu unsur kesejahteraan yang harus diwujudkan dalam bentuk pemberian berbagai upaya kesehatan kepada seluruh masyarakat melalui penyelenggaraan pembangunan kesehatan yang berkua-litas dan terjangkau oleh masyarakat sesuai dengan cita-cita bangsa Indonesia se-bagaimana dimaksud dalam pancasila dan Undang-Undang Dasar 1945 (Konsideran Menimbang UU Nomor 36 Tahun 2009 Tentang Kesehatan dan UU Nomor 29 Tahun 2004 Tentang Praktik Kedok-teran).

Pembangunan kesehatan diarahkan guna tercapainya kesadaran, kemauan dan kemampuan untuk hidup sehat bagi setiap penduduk, agar dapat mewujudkan derajat kesehatan yang optimal bagi masyarakat bagi masyarakat dengan karakteris-tik tersendiri yang dipengaruhi oleh perkembangan ilmu pengetahuan kesehatan, ke-majuan teknologi dan kehidupan sosial ekonomi masyarakat yang harus tetap mam-pu meningkatkan pelayanan yang lebih bermutu dan terjangkau oleh masyarakat yang harus tetap mampu meningkatkan pela-yanan yang lebih bermutu dan terjang-kau oleh masyarakat agar terwujud derajat kesehatan yang setinggi-tingginya,dalam rangka mencapai cita-cita bangsa Indonesia (Konsideran menimbang UU nomor 29 Tahun 2004 Tentang Praktik Kedokteran dan UU Nomor 44 Tahun 2009).

Telah diketahui bahwa rumah sakit merupakan salah satu tempat yang padat akan modal, teknologi, serta sumber daya manusia, sehingga sering terjadi tumpang tindih aturan baik internal ataupun eksternal, karenanya dalam kegiatan pemberian pelayanan kesehatan muncul banyak masalah mulai dari aspek pelayanan secara administrasi, etika, disiplin, bahkan sampai pada dugaan tindakan kedokteran yang salah. Kebutuhan perbaikan kesehatan terhadap pasien, juga diatur dalam Pasal $28 \mathrm{H}$ ayat (1) UUD 1945 mengatur bahwa "Setiap orang berhak hidup sejahtera lahir dan batin, bertempat tinggal, dan mendapatkan lingkungan hidup yang baik dan sehat serta berhak memperoleh pelayanan kesehatan".

Selain itu, kebutuhan perbaikan kesehatan pasien juga memiliki kaitan dengan hak atas perawatan kesehatan (the right to health care) yang merupakan bagian penting dari hak asasi manusia (HAM) yang diatur dalam The Universal Declaration of Human Right tahun 1948. Rumah sakit adalah organisasi penyelenggaraan pelayanan publik yang mem-punyai tanggung jawab atas setiap pelayanan kesehatan yang di-selenggarakannya. Tang-gung jawab tersebut yaitu, menyelenggarakan pelayanan ke-sehatan yang bermutu terjangkau berdasarkan prinsip aman, menyeluruh, non dis-kriminatif, partisipatif, dan memberikan perlindungan bagi masyarakat sebagai peng-guna jasa pelayanan kesehatan (health receiver), juga bagi penyelenggara pelayanan kesehatan demi untuk mewujudkan derajat kesehatan yang setinggi-tingginya (Syah-rul Mahfud, 2012: 61). Sebagaimana diatur dalam Pasal 46 UU Nomor 44 Tahun 2009 Tentang Rumah Sakit, bahwa rumah sakit bertang-gung jawab secara hukum terha-dap semua kerugian yang ditimbulkan atas kelalaian yang dilakukan oleh tenaga ke-sehatan (termasuk dokter/dokter gigi) di rumah sakit. 
Tanggung jawab hukum rumah sakit dalam pelaksanaan pelayanan kesehatan terhadap pasien dapat dilihat dari aspek etika profesi, disiplin, dan secara khusus hu-kum pidana terkait dengan tindakan kedokteran yang diduga terjadi kesalahan medis ataupun pelayanan medis lain yang tidak dilaksanakan oleh segenap unsur pelaya-nan kesehatan dengan baik. Perlu diketahui kedudukan rumah sakit secara hukum pada saat sekarang berbeda jauh dengan kedudukannya terdahulu, di mana rumah sakit tidak bisa dimintai tanggung jawab hukum khususnya hukum pidana, dikarena-kan rumah sakit masih dianggap sebagai lembaga sosial (doctrin of charitable immu-nity) yang apabila diminta tanggung jawab hukum pidana, maka akan mengurangi ke-mampuan menolong pasien. Selain itu juga, sebagaimana yang telah diajarkan dalam pengantar ilmu hukum bahwa subjek hukum terdiri dari orang/manusia (naturlijke persoon) dan badan hukum/korporasi (recht persoon). Karena perkembangan dan pertumbuhan korporasi dampaknya dapat menimbulkan efek negatif, maka kedudu-kan korporasi mulai bergeser dari subjek hukum biasa menjadi subjek hukum pidana (Enchede dan Heidjer, 1982: 271).

Terkait persoalan tersebut, khususnya dokter ataupun dokter gigi, selalu dihadapkan dengan permasalahan hukum khususnya hukum pidana, di mana dalam ka-sus tersebut dokter sering beranggapan bahwa tanggung jawab akibat dari kesalahan tindakan kedokteran tersebut, harus ditanggung secara pribadi artinya rumah sakit sebagai korporasi yang merupakan tempat dokter bekerja memberi pelayanan kese-hatan tidak bisa dimintai pertanggungjawaban pidana. Sedangkan dalam persoalan yang lain, pasien juga punya angga-pan bahwa dalam tindakan kedokteran yang didu-ga salah tersebut, hanya menjadi tanggung jawab hukum pidana dokter, dikarenakan dokter ataupun dokter gigi yang secara langsung bersentuhan dengan pasien dika-renakan pola hubungan terapeutik. Sehingga dampaknya dalam beberapa tahun ter-akhir, semenjak UU Nomor 44 Tahun 2004 Tentang Rumah Sakit disahkan jarang se-kali masyarakat, dalam hal ini pasien, melakukan upaya hukum pidana, untuk me-minta pertanggung jawaban pidana rumah sakit dalam proses hukum pidana (crimi-nal justice system) sebagaimana diatur dalam Kitab Undang-Undang Hukum Acara Pi-dana. Maka dengan ini, penulis hendak mengajukan pertanyaan sederhana apakah Rumah Sakit sebagai korporasi dapat dimintai tanggung jawab hukum pidana, tujuan esensialnya untuk menjawab persoalan, serta memberi sumbangsi keilmuan baik terhadap akade-misi, praktisi, penegak hukum, sampai kepada masyarakat luas.

\section{B. PEMBAHASAN}

\section{Ruang Lingkup Hukum Pidana}

Istilah kesalahan berasal dari kata "schuld" yang sampai saat ini belum resmi di-akui sebagai istilah ilmiah yang mempunyai pengertian pasti, namun sudah sering dipergunakan dalam penulisan-penulisan. Pengertian kesalahan menurut Pompe 
ialah kesalahan mempunyai tanda sebagai hal yang tercela (verwijtbaarheid) yang pa-da hakekatnya tidak mencegah kelakuan yang bersifat melawan hukum (der wederre-chtelijke gedraging). Ke-mudian dijelaskan pula hukum di dalam permusan hukum positif, yaitu mempunyai kesengajaan dan kealpaan (opzet en onachtzaamheid) dan kemampuan bertanggung jawab (toerekenbaarheid) (Bambang Purnomo, 1982: 135).

Namun demikian, hal tersebut tidak berarti bahwa perbuatan yang diatur da-lam rumusan pidana selalu dapat dimintai pertanggung jawaban pidana. Untuk me-menuhi syarat tersebut, maka dalam suatu perbuatan tersebut harus mempunyai si-fat melawan hukum, dapat dicela, dan dapat dipertanggungjawabkan. Perbuatan ma-nusia dapat dipidana tidak hanya karena memiliki keyakinan atau niat, namun juga hanya melakukan (aktif) atau tidak melakukan (pasif) dapat dijatuhi pidana. Terma-suk juga dapat dianggap sebagai perbuatan manusia di sini adalah badan hukum. Pada ruang lingkup rumusan delik semua unsur rumu-san delik yang tertulis harus di-penuhi. Bersifat melawan hukum artinya suatu perbuatan yang memenuhi semua un-sur rumusan delik yang tertulis (misalnya sengaja membunuh orang lain) tidak dapat dipidana kalau tidak bersifat melawan hukum, misalnya seorang tentara sengaja membunuh lawannya dalam perang. Sedangkan maksud dapat dicela adalah suatu perbuatan yang memenuhi semua unsur delik yang tertulis dan juga bersifat melawan hukum, tetapi tidak dapat dipidana kalau tidak dapat dicela pelakunya. Sifat melawan hu-kum dan sifat dapat dicela itu merupakan syarat umum suatu perbuatan dapat dipidana se-kalipun tidak disebut dalam rumusan delik (Schaffmeister, 2011: 25-26).

Kesalahan dalam arti luas meliputi kesengajaan, kelalaian, dan dapat dipertanggungjawabkan. Ketiga-tiganya merupakan unsur subyektif syarat pemidanaan atau jika kita mengikuti golongan yang memasukkan unsur kesalahan dalam arti luas ke dalam penger-tian delik (strafbaar feit) sebagai unsur subyektif delik, dapat ditam-bahkan pula unsur ke-empat yaitu tiadanya alasan pemaaf. Pompe dan Jonkers, me-masukkan juga "melawan hu-kum" sebagai kesalahan dalam arti luas disamping "sengaja" atau "kesalahan" (schuld) dan dapat dipertanggungjawabkan (toerekening-svatbaar heid) atau istilah Pompe toereken-baar. Tetapi kata Pompe, melawan hukum (wederrechtelijkheid) terletak di luar pelangga-ran hukum, sedangkan sengaja, ke-lalaian (onachtzaamleid), dan dapat dipertanggung jawabkan terletak di dalam pe-langgaran hukum. Selanjutnya, sengaja dan kelalaian (onachtzaamleid) harus dilaku-kan secara melawan hukum supaya memenuhi unsur "kesalahan" dalam arti luas. Sejak tahun 1930 dikenalkanlah asas "tiada pidana tanpa kesalahan" (Jerman: Keine Straf ohne Schuld), hanya orang yang bersalah atau perbuatan yang dipertanggung-jawabkan kepada pembuat yang dapat dipidana (Andi Hamzah, 2008: 111-112).

Adakalanya isi kesalahan tersebut di atas dapat disimpulkan menjadi tiga bagian, yaitu (Bambang Poernomo, 1982: 138):

a. Tentang kemampuan bertanggung jawab (toerekeningsvatbaarheid) orang yang melakukan perbuatan; 
b. Tentang hubungan batin tertentu dari orang yang melakukan perbuatan yang berbentuk kesengajaan atau kealpaan (dolus atau culpa);

c. Tentang tidak adanya alasan penghapus kesalahan/pemaaf (schuld ontbreekt).

Pada Hukum Pidana, kesalahan dibagi dalam dua bentuk yakni kesengajaan dan kealpaan. Pertama, kesengajaan itu secara alternatif dapat ditujukan kepada tiga elemen perbuatan pidana sehingga terwujud kesengajaan terhadap perbuatan, kesengajaan terhadap akibat, dan kesengajaan terhadap hal ihwal yang menyertai perbuatan pidana. Wujud ke-sengajaan terhadap perbuatan atau yang dikenal dengan opzet formil tidak menimbulkan persoalan di antara para ahli hukum. Akan tetapi wujud kesengajaan terhadap akibat dan terhadap hal ihwal yang menyertai perbuatan pidana atau dikenal dengan opzet materiil, timbul pertentangan yang tajam antara dua aliran dari teori kehendak (de wilstheori) dan teori pengetahuan/dapat mem-bayangkan (de voorstellingstheorie). Teori kehendak yang diajarkan oleh Von Hippel (Jerman) dengan keterangannya tentang "Die Grenze von Vorztatz und Fahrlassing-keit" menerangkan, sengaja adalah kehendak untuk menimbulkan akibat dari per-buatan itu, dengan kata lain apabila seseorang melakukan perbuatan tertentu, tentu saja ia menghendaki timbulnya akibat dari perbuatannya ataupun hal ihwal yang me-nyertainya. Selain itu, Teori pengetahuan/dapat membayangkan/persangkaan yang diajar-kan oleh Frank dengan karangannya tentang "Vorstellung und Wille in der Modernen Doluslehre" 1980 dan "Ueber den Aufbau des Schulsbegriffs" 1907 mene-rangkan, bahwa tidaklah mungkin sesuatu akibat atau hal ihwal yang menyertai itu dapat dikehendaki, dengan kata lain perbuatannya memang dikehendaki akan tetapi akibat atau hal ihwal yang menyertai itu tidak dapat dikatakan sebagai kehendak si pelaku, karena manusia dapat membayangkan/menyangka terhadap akibat atau hal ihwal yang menyertai (Bambang Purnomo, 1982: 156). Jadi, menurut teori ini adanya kesengajaan memiliki dua syarat (Moeljatno, 2008: 190):

a. Terdakwa mengetahui kemungkinan adanya akibat keadaan yang merupakan delik.

b. Sikapnya terhadap kemungkinan itu andaikata sungguh terjadi ialah risiko yang mau tidak mau ditanggung oleh si pelaku.

Kedua, undang-undang tidak memberikan defenisi apakah kealpaan/kelalaian itu, namun memori penjelasan (Memori van Toelichting) mengatakan, bahwa ke-lalaian (culpa) terletak antara sengaja dan kebetulan. Bagaimanapun juga culpa di-pandang lebih ringan di-banding dengan sengaja. Oleh karena itu HazewinkelSuringa mengatakan bahwa delik culpa itu merupakan delik semu (quasidelict) sehingga di-adakan pengurangan pidana. Culpa dapat pula dikatakan terletak antara sengaja dan kebetulan. Hazewinkel-Suringa menyebutkan bahwa di negara-negara Anglo-Saxon dikenal pula hal yang serupa yang disebut per infortuninum the killing occured acci-dently. Memori jawaban Pemerintah (MvA) me-ngatakan bahwa siapa yang melaku-kan kejahatan dengan sengaja berarti mempergunakan kemampuannya dengan salah sedangkan siapa karena salahnya melakukan 
kejahatan berarti tidak memperguna-kan kemampuannya sebagaimana mestinya. Terkait dengan culpa, Van Hamel mem-bagi culpa atas dua jenis yakni kurang melihat ke depan yang perlu dan kurang hati-hati yang perlu (Andi Hamzah, 2008: 133).

Kealpaan/kelalaian sebagai terjemahan dari negligence dalam arti umum ada-lah bukan merupakan kejahatan. Seseorang dikatakan lalai apabila ia bersikap tak acuh, tak peduli, tidak memperhatinkan kepentingan orang lain sebagaimana lazim-nya dalam pergaulan masyarakat. Selain itu, Jonkers menyebut unsur-unsur kesala-han (kealpaan) dalam hukum pidana yakni, bertentangan dengan hukum, akibat se-benarnya dapat dibayangkan dan perbuatannya dapat dipersalahkan (Moh. Hatta, 2013: 186). Kealpaan (culpa) berarti pula kurang mengindahkan larangan sehingga tidak berhati-hati dalam melakukan sesuatu perbuatan yang objektif kausal menim-bulkan keadaan yang dilarang. Undang-Undang tidak memberi definisi apakah keal-paan itu. Hanya Memori Penjara (Memorie van Toelichting) megatakan, bahwa keal-paan terletak antara sengaja dan kebetulan. Bagaimanapun juga kealpaan itu dipan-dang lebih ringan dibanding dengan kesengajaan (dolus). Oleh karena itu Hazewinkel-Suringa mengatakan bahwa delik culpa itu delik semu (quasidelict) sehingga diadakan pengurangan pidana (Andi Hamzah, 2010: 133).

Jika maksudnya demikian, maka culpa mencakup semua makna kesalahan da-lam arti luas yang bukan merupakan kesengajaan. Perbedaan antara kesengajaan dan kealpaan ialah bahwa dalam kesengajaan ada sifat yang positif, yaitu adanya kehen-dak dan persetujuan yang disadari dari bagian-bagian delik, sedang sifat positif ini ti-dak ada dalam keal-paan). Oleh karena itu dapatlah dimengerti, bahwa kesalahan da-lam arti luas adalah kesengajaan (dolus), sedangkan dalam arti sempit ialah kealpaan (culpa) (Moeljatno, 2008: 216-217). Van Hamel mengatakan bahwa kealpaan itu me-ngandung dua syarat, yaitu tidak mengadakan penduga-duga sebagaimana diharus-kan oleh hukum, serta tidak mengadakan penghati-hatian sebagaimana diharuskan oleh hukum (Moeljatno, 2008: 217).

\section{Tanggung Jawab Pidana Korporasi}

Membahas persoalan tanggung jawab pidana ternyata terdapat dua pandangan, satu di antaranya adalah pandangan monoistis. Terkait dengan hal tersebut, Simon merumuskan strafbaar feit (tindak pidana) sebagai "Eene starfbaar gestelde, onrechtmatige, met schuld in verband staande handeling van een torekeningvatbaar persoon" (suatu perbuatan yang oleh hukum diancam dengan hukuman, bertentangan dengan hukum, dilakukan oleh seorang yang bersalah, dan orang itu dianggap ber-tanggung jawab atas perbuatannya). Sedangkan menurut aliran monoisme, unsur-unsur strafbaar feit itu meliputi unsur perbuatan yang lazim disebut unsur objektif, ataupun unsur pembuat yang lazim dinamakan subjektif. Maka dari itu, dicampurnya unsur perbuatan dan unsur pembuatnya, dapat disimpulkan bahwa strafbaar feit adalah sama dengan syarat-syarat penjatuhan 
pidana, sehingga seolah-olah bahwa kalau terjadi strafbaar feit maka pasti pelakunya dapat dipidana (Muladi, 2010: 63).

Menurut A.Z. Abidin, bahwa penganut aliran monoistis terhadap strafbaar feit merupakan mayoritas di seluruh dunia. Mereka memandang unsur pembuat delik sebagai bagian dari strafbaar feit. Misalnya Ch.J.E. Enschede dan Heidjer melukiskan strafbaar feit sebagai een daad dader-complex (pelaku kejahatan khusus). Adapun J.M. van Bemmelen tidak memberikan definisi teoritis, namun menyatakan harus dibedakan antara bestanddelen (perilaku) dan elemen strafbaar feit (A.Z. Abidin, 1983: 44-45).

Terkait dengan masalah tanggung jawab pidana, Barda Nawawi Arief menyatakan bahwa adanya tanggung jawab pidana harus jelas terlebih dahulu siapa yang dapat dipertanggungjawabkan. Ini berarti harus dipastikan lebih dahulu siapa yang dinyatakan sebagai pembuat suatu tindak pidana. Masalah ini menyangkut masalah subjek tindak pidana yang pada umumnya sudah dirumuskan oleh pembuat undangundang untuk tindak pidana yang bersangkutan. Namun dalam kenyataannya, memastikan siapa pembuat suatu tindak pidana tidaklah mudah. Barda Nawawi Arief juga menyatakan, bahwa setelah pembuat ditentukan, bagaimanakah pertanggungjawaban pidananya? Masalah pertanggungjawaban pidana ini merupakan segi lain dari subjek tindak pidana yang dapat dibedakan dari masalah pembuat tindak pidana. Artinya, pengertian subjek pembuat pidana dapat meliputi dua hal, yaitu siapa yang melakukan tindak pidana (pembuat pidana) dan siapa yang dapat dipertanggung jawabkan dalam hukum pidana, tetapi tidaklah selalu demikian. Masalah ini tergan-tung juga pada cara atau sistem perumusan pertanggungjawaban yang ditempuh oleh pembuat un-dang-undang (Barda Nawawi Arief, 1982: 105107).

Sebagaimana yang dijelaskan di atas, Muladi menjelaskan pula bagaimana kalau yang melakukan tindak pidana ialah korporasi atau badan hukum (recht persoon)? Tanpa spesifikasi yang jelas atau identitas yang jelas, maka masalah kesusilaan siapa pembuatnya akan selalu timbul, dan masalah ini membawa suatu konsekuensi tentang masalah pertang-gungjawaban pidana korporasi. Terkait model pertang-gungjawaban pidana korporasi dalam hukum pidana terdapat beberapa undang-undang yang selanjutnya akan dibahas di ba-wah. Mengenai kedudukan sebagai pem-buat dan sifat pertanggung jawaban pidana korpo-rasi, terdapat model pertanggungj-awaban korporasi sebagai berikut (Muladi, 2010: 63):

a. Pengurus korporasi sebagai pembuat dan pengurus yang bertanggung jawab.

b. Korporasi sebagai pembuat dan pengurus bertanggung jawab.

c. Korporasi sebagai pembuat dan juga sebagai yang bertanggung jawab.

Terkait dengan pengurus korporasi sebagai pembuat pidana dan pengurus yang bertanggung jawab, maka kepada pengurus korporasi dibebankan kewajibankewajiban tertentu. Kewajiban yang dibebankan itu sebenarnya adalah kewajiban dari korporasi. Pe-ngurus yang tidak memenuhi kewajiban itu diancam pidana. Sehingga dalam sistem ini ter-dapat alasan yang menghapus pidana. Adapun dasar 
pemikirannya ialah bahwa korporasi itu sendiri tidak dapat dipertanggungjawabkan terhadap suatu pelanggaran, tetapi selalu penguruslah yang melakukan delik itu, sehingga karenanya penguruslah yang diancam pidana dan dipidana (Roslan Saleh, 1984: 50-51).

Tentang pertanggungjawaban korporasi tedapat suatu ketentuan yang diatur dalam Pasal 169, Pasal 398, dan Pasal 399 KUHP. Sebagai salah satu contoh adalah Pasal 169 yang mengatur:

a. Turut serta dalam perkumpulan yang bertujuan melakukan kejahatan atau turut serta dalam perkumpulan lainnya yang dilarang oleh aturanaturan umum diancam dengan pidana penjara paling lama enam tahun.

b. Turut serta dalam perkumpulan yang bertujuan melakukan pelanggaran diancam dengan penjara paling lama sembilan bulan atau pidana denda paling ba-nyak empat ribu lima ratus rupiah.

c. Terhadap pendiri atau pengurus pidana dapat ditambah sepertiga (KUHP).

Berhubungan dengan korporasi sebagai pembuat dan pengurus bertanggung jawab, maka dapat ditegaskan bahwa kemungkinan korporasi dapat disebut sebagai pembuat. Pengurus ditunjuk sebagai yang bertanggung jawab sedangkan yang dipan-dang dilakukan oleh korporasi ialah apa yang dilakukan oleh alat perlengkapan kor-porasi menurut wewenang berdasarkan anggaran dasarnya. Tindak pidana yang di-lakukan oleh korporasi adalah tindak pidana yang dilakukan oleh seseorang sebagai pengurus dari badan hukum tersebut. Sifat dari perbuatan yang menjadikan tindak pidana itu adalah onpersoonlijk (subjek hukum yang memiliki wewenang dalam se-buah korporasi). Orang yang memimpin korporasi bertanggung jawab pidana, terle-pas dari apakah ia tahu ataukah tidak tentang dilakukannya perbuatan itu (Roeslan Saleh, BPHN: 1984).

Apabila dikaitkan dengan doktrin Vicarious Liability sebagai doktrin tanggung jawab korporasi dalam hukum pidana, bahwa tanggung jawab dibebankan kepa-da seseorang atas perbuatan orang lain (the legal responsibility of one person for the wrongful acts of another). Doktrin ini berlaku pada perbuatan yang dilakukan orang lain dalam ruang ling-kup pekerjaan atau jabatan, yang tentunya memiliki hubungan hukum dalam pekerjaan tersebut. Doktrin ini, walaupun setiap (naturlijke persoon atau recht persoon) tidak melaku-kan sendiri tindak pidana dan tidak punya kesala-han pidana dapat dimintai tanggung jawab pidana korporasi. Doktrin ini hanya ber-laku dalam perbuatan pidana yang mensyaratkan adanya hubungan terapeutik anta-ra buruh dalam hal ini dokter dan direktur rumah sakit (Romli Atasasmita, 1989: 93). Pemidanaan korporasi biasanya menganut apa yang dinamakan "bipunishment pro-visions" artinya baik pelaku ataupun korporasi dapat dijadikan sebagai subjek hu-kum pidana. Pada rancangan KUHP 2004-2005, Pasal 38 ayat (2) menyatakan bahwa "dalam hal ditentukan oleh undang-undang setiap orang dapat dipertanggung jawab-kan atas tindak pidana yang dilakukan oleh setiap orang lain". 
Bagaimanakah cara meminta pertanggungjawaban pidana korporasi? Menjawab pertanyaan ini akan berhubungan dengan peraturan perundang-undangan yang berlaku, bahwa korporasi dapat dipertanggungjawabkan secara langsung. Salah satu ketentuan yang menempatkan korporasi sebagai subjek hukum pidana sehingga da-pat dimintai pertang-gung jawaban adalah Pasal 15 ayat (2) UU No 7 Drt Tahun 1955 Tentang Tindak Pidana Ekonomi yang mengatur bahwa "suatu tindak pidana ekono-mi dilakukan juga oleh atas nama suatu badan hukum, suatu perseroan, suatu perseri-katan orang, atau suatu yayasan, jika tindakan dilakukan oleh orang-orang baik ber-dasarkan hubungan maupun berdasarkan hubungan lain bertindak dalam lingkungan badan hukum, perseroan, perserikatan, atau yayasan itu tidak peduli apakah orang-orang itu masing-masing tersendiri melakukan tindak pidana ekonomi itu atau pada mereka bersama-sama ada anasir-anasir tindak pidana tersebut"( Muladi, 2010: 63).

Korporasi sebagai pelaku tindak pidana dalam hukum positif telah diakui bah-wa korporasi dapat dipertanggung jawabkan secara hukum pidana, dan dapat dija-tuhkan pidana. Negara Belanda menentukan korporasi sebagai pelaku tindak pidana berdasarkan pada Arrest "Kleuterschool Babbel", yang menjelaskan bahwa perbuatan dari perorangan dapat dibebankan pada badan hukum/korporasi, apabila perbuatan tersebut tercermin dalam lalu lintas sosial sebagai perbuatan dari badan hukum (An-di Hamzah, 1984: 263).

Korporasi di negara Anglo Saxon pada prinsipnya dapat dipertanggungjawab-kan sama dengan orang pribadi berdasarkan asas indentifikasi, akan tetapi ada bebe-rapa pengecualian, seperti yang dikemukakan Barda Nawawi Arif (1988: 40) yaitu:

a. Perkara yang menurut kodratnya tidak dapat dilakukan oleh korporasi, missalnya bigami, perkosaan, dan sumpah palsu.

b. Perkara satu-satunya pidana dapat kenakan kepada koporasi, misalnya pidana penjara atau pidana mati.

Senada tentang delik-delik yang tidak dapat dilakukan korporasi, Sudarto menyatakan bahwa dalam sistem hukum Inggris korporasi bisa dipertanggungjawab-kan secara umum. Secara teori korporasi bisa melakukan delik apa saja akan tetapi ada pembatasnya. Delik-delik yang tidak dapat dilakukan oleh korporasi ialah delik-delik sebagai berikut (Su-darto, 1987: 27):

a. Delik yang satu-satunya ancaman pidannya hanya bisa dikenakan kepada orang biasa, misalnya pembunuhan.

b. Delik yang hanya bisa dilakukan oleh orang biasa, misalnya bigami dan perkosaan.

Berdasarkan hal tersebut, maka Muladi setuju bahwa korporasi tidak dapat dipertanggung jawabkan untuk seluruh macam delik seperti di Belanda, namun harus ada pembatasan, yaitu delik-delik yang bersifat personal, yang menurut kodratnya bisa dilakukan oleh manusia seperti perkosaan, bigami, pembunuhan, maka tidak da-pat dipertanggung jawabkan kepada korporasi (Muladi, 2010: 101). 
Tanggung jawab pidana korporasi sangat erat kaitannya dengan doktrin strict liability, selain doktrin vicarious liability yang telah dijelaskan sebelumnya, strict liability menjelaskan bahwa seseorang sudah dapat dipertanggungjawabkan untuk tindak pidana tertentu walaupun pada diri orang itu tidak ada kesalahan (mens rea). Secara singkat, strict liability diartikan sebagai liability without fault (pertanggung-jawaban pidana tanpa kesala-han) (Barda Nawawi Arief, 1984: 68).

Pemahaman di atas dimasukan ke dalam ketentuan Pasal 51 Sr. yang kemudian memuat isi yang jauh berbeda, yaitu (Jan Ramemelink, 2003: 102):

a. Tindak pidana dapat dilakukan baik oleh perorangan ataupun oleh korporasi.

b. Jika suatu tindak pidana dilakukan oleh korporasi, penentuan pidana dapat dijalankan dan sanksi pidana ataupun tindakan (maatregelen) yang disediakan dalam perundang-undangan sepanjang berkenaan dengan korporasi dapat dijatuhkan. Dalam hal ini, pengenaan sanksi dapat dilakukan terhadap korporasi sendiri, atau mereka yang secara faktual memberikan perintah untuk melakukan tindak pidana.

Pengertian korporasi ditemukan dalam hukum perdata, sebagaimana diatur dalam Pasal 1 ayat (1) UU No 40 Tahun 2007 Tentang Perseroan Terbatas: "Perseroan Terbatas, yang selanjutnya disebut perseroan, adalah badan hukum yang merupakan persekutuan modal, didirikan berdasarkan perjanjian, melakukan kegiatan usaha dengan modal dasar yang seluruhnya terbagi dalam saham dan memenuhi persyara-tan yang ditetapkan dalam undang-undang ini serta peraturan pelaksanaannya".

Von Gierke mengemukakan bahwa dalam perseroan terdapat orang yang ter-diri atas pemegang saham dan pengurus. Pemegang saham dan pengurus bukanlah fiksi, melainkan orang yang sesungguhnya memiliki kecakapan untuk berbuat serta juga mempunyai kehendak sendiri. Ketika membentuk dan memformulasikan kehen-dak tersebut, mereka bertindak sebagi organ perseroan. Oleh karena itu, kehendak tersebut merupakan kehendak dari perseroan sebagai badan hukum (Fahmi, 2015: 81).

Terkait dengan tanggung jawab pidana korporasi merupakan pengembangan dari kajian hukum perdata Belanda yang kemudian dibawa ke Indonesia melalui kodi-fikasi Burgerlijk Wetboek (BW) sebagaimana diatur dalam Pasal 1367 KUH Perda-ta/BW bahwa "Majikan-majikan dan mereka yang mengangkat orang lain untuk me-wakili urusan-urusan mereka adalah bertanggung jawab tentang kerugian yang di-tertibkan oleh pelayan-pelayanan atau bawahanbawahan mereka di dalam melaku-kan pekerjaan untuk nama orang-orang itu dipakainya". Pasal ini memiliki kaitan dengan doktrin vicarious liability dan strict liability yang dijelaskan pada bagian sebelumnya.

Selain itu menurut Subekti, bahwa ketika manusia sebagai subjek hukum, ma-ka badan hukum juga merupakan subjek hukum, yaitu memiliki hak dan kewajiban seperti manusia. Badan hukum dapat menjadi subjek hukum dengan memenuhi be-berapa syarat sebagai berikut (Subekti, 1989: 21): 
a. Jika badan hukum tersebut memiliki kekayaan sendiri yang terpisah dari keka-yaan orang perorangan yang bertindak dalam badan hukum itu;

b. Jika badan hukum tersebut mempunyai kepentingan yang sama dengan kepentingan orang perorangan, yaitu kepentingan sekelompok orang dengan peranta-ra pengurusnya.

Pemidanaan terhadap korporasi, sekalipun sering dikaitkan dengan permasa-lahan finansial, namun sebenarnya mengandung tujuan yang lebih jauh. Hal ini ter-ungkap dari pandangan Friedman (Muladi, 2010: 148): "The main effect and usefulnes of a criminal conviction imposed upon a corporation be see either in any personal injury or, in most cases, in the financial detriment, but in the public opprobrium and stigma that attaches to a criminal conviction" (efek utama dan kegunaan dari hukum pidana yang dikenakan terha-dap korporasi akan memberi banyak kerugian korporasi, namun stigma dan penghinaan publik yang melekat dalam hukum pidana juga akan merugikan keuangan korporasi).

Sistem pertanggungjawaban pidana korporasi dalam perspektif kebijakan kriminal dan kebijakan pidana, tidak lepas dari tahap formulasi yang sangat penting, karena apabila terdapat kelemahan perumusan dapat menghambat penegakkan hukum dalam rangka per-tanggungjawaban korporasi dalam hukum pidana. Tahapan formulasi yang dimaksud di dalamnya menyangkut tentang definisi korporasi, latar belakang tahap perkembangan korporasi sebagai subjek hukum pidana, perkembangan teori-teori pertanggung jawaban pidana, dan model pengaturan jenis sanksi pidana untuk korporasi (Muladi, 2010: 220).

\section{Rumah Sakit}

Ketika membahas Rumah Sakit sebagai institusi layanan kesehatan kapada masyarakat luas, maka kita harus diajak menelaah konsideran rumah sakit yang dimuat dalam UU No 44 Tahun 2009 Tentang Rumah Sakit. Rumah Sakit adalah institusi pelayanan kesehatan bagi masyarakat dengan karateristik tersendiri yang di-penga-ruhi oleh perkembangan ilmu pengetahuan kesehatan, kemajuan teknologi, dan kehi-dupan sosial ekonomi masyarakat yang harus tetap mampu meningkatkan pelayanan yang lebih bermutu dan terjangkau oleh masyarakat agar terwujud derajat kesehatan yang setinggi-tingginya.

Pasal 1 ayat (1) UU No 44 Tahun 2009 Tentang Rumah Sakit dengan jelas me-ngatur pengertian rumah sakit yakni rumah sakit adalah institusi pelayanan keseha-tan yang menyelenggarakan pelayanan kesehatan perorangan secara paripurna yang menyediakan pelayanan rawat inap, rawat jalan, dan gawat darurat. Menurut Amir Ilyas (2014: 10), rumah sakit bukan lagi menjadi sekedar wadah, sarana tempat di-lakukannya pelayanan kese-hatan, namun juga sebagai subjek hukum. Sebagai subjek hukum, maka rumah sakit mempunyai hak dan kewajiban.

Rumah Sakit sebagai salah satu sarana kesehatan dapat diklafikasi sebagai berikut (Sri Paptianingsih, 2006: 93-94):

a. Berdasarkan pada pemilik dan penyelenggara. 
b. Rumah Sakit dapat dibedakan menjadi rumah sakit pemerintah dan rumah sakit swasta. Rumah sakit pemerintah dimiliki dan diselenggarakan oleh Departemen Kesehatan, Pemerimntah Daerah, TNI dan POLRI, serta BUMN. Rumah sakit Swasta dimiliki dan diselenggarakan oleh yayasan yang sudah disahkan sebagai badan hukum dan badan lain yang bersifat sosial.

c. Berdasarkan pada jenis pelayanan

d. Berdasarkan bentuk pelayanan, rumah sakit dapat dibedakan menjadi Ru-mah Sakit Umum (RSU) dan Rumah Sakit Khusus. Rumah Sakit Umum adalah rumah sakit yang memberikan pelayanan kesehatan untuk semua jenis penyakit dari yang bersifat dasar sampai dengan subspesialistik. Ru-mah Sakit Khusus ialah rumah sakit yang menyelenggarakan pelayanan kesehatan berdasarkan jenis penyakit tertentu atau disiplin ilmu. Misal-nya Rumah Sakit Paru-Paru, Rumah Sakit Jantung, dan lain sebagainya.

e. Berdasarkan klasifikasi

f. Berdasarkan pada kemampuan pelayanan, ketenagaan, fisik, dan peralatan yang dapat tersedia, rumah sakit umum pemerintah dan daerah dikla-sifikasi sebagai berikut:

1) RSU kelas A mempunyai fasilitas dan kemampuan pelayanan medis spesialistik luas dan subspesialistik luas.

2) RSU kelas B mempunyai fasilitas dan kemampuan pelayanan medis se-kurang-kurangnya sebelas spesialistik dan subspesialistik terbatas.

3) RSU kelas C mempunyai fasilitas dan kemampuan pelayanan medis spe-sialistik dasar.

4) RSU kelas C mempunyai fasilitas dan kemampuan pelayanan medis dasar.

Rumah Sakit hakikatnya ialah sebuah organisasi yang dibentuk oleh suatu Ba-dan Hukum (Pemerintah, Perjan, Yayasan, Perseroan Terbatas, Perkumpulan). Salah satu prin-sip dari setiap organisasi ialah unsur "authority". Jika dilihat dari sudut ma-najemen, maka dalam setiap organisasi termasuk organisasi rumah sakit harus ada pucuk pimpinan yang memikul tanggungjawab dan wewenang tertinggi (Amir, 2014: 18).

Hermien Hadiati Koeswadji (Hermien, 1984: 107) menyatakan bahwa dalam lalu lintas hubungan hukum yang terjadi dalam masyarakat sebagai suatu sistem sosial, maka dengan demikian rumah sakit merupakan organ yang mempunyai kemandirian untuk melakukan perbuatan hukum (rechtshandeling). Rumah sakit bukan ma-nusia dalam arti persoon yang dapat berbuat dalam lalu lintas hukum dalam masya-rakat sebagai manusia (naturlijkepersoon) dan karenanya rumah sakit merupakan rechts persoon. Hukum yang telah menjadikan rumah sakit sebagai rechts persoon dan oleh karena itu rumah sakit juga dibebani dengan hak dan kewajiban menurut hukum atas tindakan yang dilakukannya. 
Terhadap rumah sakit swasta, Dirjen Pelayanan Medik telah mengeluarkan Keputusan Nomor YM.02.04.4.5.02270 Tahun 2005 Tentang Pedoman, Tugas Pokok, Peran dan Fungsi antara Pemilik, Dewan Penyantun, dan Pengelola pada rumah sakit swasta, telah menentukan hal-hal sebagai berikut (Amir Ilyas, 2010: 23):

a. Pemilik adalah badan hukum yang memiliki rumah sakit.

b. Pengelola adalah direktur rumah sakit dan jajaranya.

c. Dewan penyantun adalah kelompok pengarah/penasihat yang keanggotaannya terdiri dari unsur-unsur pemilik rumah sakit, unsur pemerintah, unsur profesional dan tokoh masyarakat.

Menurut penulis, apabila kembali melihat aturan pokok yang terdapat dalam rumah sakit, sebagai aturan yang mengatur segala pelayanan kesehatan dan tenaga kesehatan khususnya direktur/pimpinan rumah sakit, pemilik serta dokter ataupun dokter gigi, maka dapat merujuk pada Hospital Bylaws, serta Standar Operasional Pro-sedur sebagai aturan pelaksana. Hospital Bylaws secara tegas mengatur hubungan antara direktur/pimpinan dan pemilik rumah sakit dengan dokter ataupun dokter gigi terkait dengan tindakan kedokteran, dimana Hospital Bylaws juga menjadi kon-stitusi bagi dokter dengan direktur/pimpinan rumah sakit/pemilik, untuk menyele-saikan konflik dan memberi perlindungan hukum khususnya bagi dokter dan dokter gigi sebagai tenaga medis.

Sebagaimana diatur dalam Medical Staff Bylaws bahwa direktur/pemilik, pim-pinan rumah sakit beserta dokter dan dokter gigi merupakan tritunggal yang ber-sama-sama secara fungsional memimpin rumah sakit dan bertanggungjawab bersa-ma terkait pelayanan medis kepada masyarakat. Seperti yang telah dijelaskan secara ringkas, terkait dengan Hospital Bylaws dan Medical Staff Bylaws, maka hukum pidana sebagai hukum publik, bisa meminta pertanggungjawaban pidana korporasi, tidak hanya terbatas pada dokter ataupun dokter gigi, namun juga pada rumah sakit seba-gai korporasi yang bertanggungjawab atas segala tindakan kedokteran yang salah, yang dilakukan oleh dokter ataupun dokter gigi kepada pasien.

\section{KESIMPULAN DAN SARAN}

\section{Kesimpulan}

Apabila melihat subjek hukum yang terdiri dari orang (naturlijke persoon) dan badan hukum/korporasi (rechts persoon) sebagimana dalam ajaran hukum pidana yang menyandang hak dan kewajiban, serta juga melihat doktrin strict liability dan vicarious liability. Atas dasar ini, walaupun korporasi tidak sebagai pembuat pidana secara langsung, terkait dengan kesalahan tindakan kedokteran dokter, ataupun tena-ga kesehatan lainnya terhadap pasien, namun dapat dimintai tanggungjawab pidana korporasi. Hal ini dikarenakan setiap dokter ataupun tenaga kesehatan memiliki hu-bungan hukum (lalu lintas kerja) dengan rumah sakit dalam hal pekerjaan sebagai pegawai dan pimpinan. Selain itu diperkuat lagi dengan Pasal 
46 UU Nomor 44 Tahun 2009 Tentang Rumah Sakit, yang mengatur bahwa "rumah sakit bertanggungjawab secara hukum terhadap semua kerugian yang ditimbulkan atas kelalaian yang dilaku-kan oleh tenaga kesehatan (termasuk dokter/dokter gigi) di rumah sakit". Perlu diketa-hui juga bahwa kategori rumah sakit dapat diminta tanggung jawab pidana korporasi, ketika unsur kesalahan pidana, melawan hukum, dan dapat dimintai pertanggung-jawaban pidana dapat terpenuhi secara hukum pidana materiil dan hukum pidana formiil.

\section{Saran}

Dari uraian singkat kesimpulan di atas, menurut penulis sudah saatnya penegak hukum dalam sistem peradilan pidana (advokat, polisi, jaksa dan hakim) tidak hanya meminta tanggung jawab hukum pidana dokter atau tenaga kesehatan yang lain. Akan tetapi sudah saatnya meminta tanggung jawab hukum rumah sakit yang ju-ga sebagai subjek hukum pidana (rechts persoon), tujuannya agar efek jera yang men-jadi salah satu tujuan hukum pidana, tidak hanya dikenakan kepada dokter atau tena-ga kesehatan lainnya yang sebagai subjek hukum (naturlijke persoon), namun juga efek jera tersebut harus diperluas dalam hal meminta tanggung jawab rumah sakit sebagai korporasi, agar ke depan dengan efek je-ra tersebut dapat mengubah sistem pelayanan kesehatan rumah sakit yang buruk seperti se-karang ini menjadi lebih baik dalam memberi pelayanan kesehatan terhadap pasien.

\section{DAFTAR PUSTAKA}

\section{BUKU DAN JURNAL}

Abidin, A.Z. (1983). Bunga Rampai Hukum Pidana. Jakarta: Pradnya Paramita.

Buamona, Hasrul (2015). Tanggung Jawab Pidana Korporasi. Medical Law-Majalah Dental dan Dental Kedokteran Gigi Edisi Maret-April 2015.

D. Schaffmeister et. al (2011). Hukum Pidana. Bandung: Citra Aditya Bakti.

Enchede, C.H.J., dan Heidjer (1982). Beginselen van Starftrecht, Derde Druk (alih bahasa R. Achamd Soemadipradja). Bandung: Alumni.

Fahmi (2015). Pergeseran Tanggung Jawab Sosial: Dari Tanggung Jawab Moral ke Tanggung Jawab Hukum. Yogyakarta: FH UII Press.

Friedman, Wolfgang (1989). Law In Changing Society (Makalah Terpetik dalam Pelaksanaan Pemidanaan oleh Muladi pada Bidang Hukum Ekonomi, FH UNKRI). Jakarta: 1989.

Hadiati Koeswadji, Hermien (tt). Hukum Kedokteran. Bandung: Citra Aditya Bakti. Hamzah, Andi (2008). Asas-Asas Hukum Pidana (Edisi Revisi). Jakarta: Rineka Cipta. (1984). Pengantar Hukum Acara Pidana Indoenesia. Jakarta: Ghalia Indoenesia.

Hatta, Moh. (2013). Hukum Kesehatan \& Sengketa Medik. Yogyakarta: Liberty.

Ilyas, Amir (2014). Pertanggungjawaban Pidana Dokter dalam Malpraktik di Rumah Sakit. Yogyakarta: Republic Institute. 
Mahmud, Syahrul (2012). Penegakkan Hukum dan Perlindungan Hukum Bagi Dokter Yang Diduga Melakukan Medikal Malpraktik. Bandung: Mandar Maju.

Moeljatno (2008). Asas-Asas Hukum Pidana. Jakarta: Rineka Cipta.

Muladi. 2010. Pertanggunjawaban Pidana Korporasi. Jakarta. Kencana.

(1982). Masalah Pemidanaan Sehubungan dengan Perkembangan Delik-

Delik Khusu dalam Masyarakat Modern. Makalah pada Seminar Perkembangan Delik-Delik Khusus dalam Masyarakat yang mengalami Modernisasi BPHN-FH UNAIR Surabaya 25 Februari 1980. Bandung: Binacipta.

(1984). Pelengkap Bahan Kuliah Hukum Pidana I. Semarang: FH UNDIP.

Arif, Barda Nawawi (1988). Perbandingan Hukum Pidana. Bahan Penyediaan Bahan Kuliah FH. UNDIP.

Paptianingsih, Sri (2006). Kedudukan Hukum Perawat dalam Upaya Pelayanan Kesehatan di Rumah Sakit. Jakarta: Raja Grafindo Persada.

Poernomo, Bambang (tt). Asas-Asas Hukum Pidana. Yogyakarta: Ghalia Indonesia.

Remmelink, Jan (2003). Hukum Pidana. Jakarta: Gramedia Pustaka Utama.

Saleh, Roslan (1984). Tentang Tindak-Tindak Pidana dan Pertanggung Jawaban Pidana. Jakarta. BPHN.

Subketi (1989). Pokok-Pokok Hukum Perdata. Jakarta: Intermasa.

Sudarto (1987). Pemidanaan, Pidana dan Tindakan Dalam Masalah-Masalah Hukum. Semarang: FH UNDIP.

\section{UNDANG-UNDANG:}

Kitab Undang-Undang Hukum Perdata.

Kitab Undang-Undang Hukum Pidana.

UU Nomor 29 Tahun 2004 Tentang Praktik Kedokteran

UU Nomor 40 Tahun 2007 Tentang Perseroan Terbatas

UU Nomor 44 Tahun 2009 Tentang Rumah Sakit. 
